\title{
Neonatal leptin treatment programmes leptin hypothalamic resistance and intermediary metabolic parameters in adult rats
}

\author{
Fabiane Pereira Toste ${ }^{1}$, Egberto Gaspar de Moura ${ }^{1}$, Patrícia Cristina Lisboa ${ }^{1}$, Aline Teixeira Fagundes ${ }^{1}$, \\ Elaine de Oliveira ${ }^{1}$ and Magna Cottini Fonseca Passos ${ }^{1,2 *}$ \\ ${ }^{1}$ Department of Physiological Sciences, Institute of Biology, State University of Rio de Janeiro, 20550-030, Rio de Janeiro, Brazil \\ ${ }^{2}$ Department of Applied Nutrition, Nutrition Institute, State University of Rio de Janeiro, 20550-030, Rio de Janeiro, Brazil
}

(Received 15 July 2005 - Revised 8 December 2005 - Accepted 8 December 2005)

\begin{abstract}
We previously showed that neonatal leptin treatment programmes higher body weight and food intake in adult rats. Here we investigate whether leptin treatment during lactation affects the anorectic effect of leptin on adult rats and their hypothalamic leptin receptors (OB-Rb) and whether those changes could have consequences on intermediary metabolism. When the offspring were born, pups were divided into two groups: the Lep group, injected daily with leptin $(8 \mu \mathrm{g} / 100 \mathrm{~g}$ body weight, subcutaneously) for the first $10 \mathrm{~d}$ of lactation, and the control group, injected daily with saline. After weaning (day 21), body weight and food intake were monitored until the rats were $150 \mathrm{~d}$ old. Food intake was higher in the Lep group (approximately $14 \%, P<0.05$ ) from day 133 onwards, and body weight was higher (approximately $10 \%, P<0.05$ ) from day 69 onwards, compared with the control group. At $150 \mathrm{~d}$ of age, the rats were tested for food intake in response to either leptin $(0.5 \mathrm{mg} / \mathrm{kg}$ body weight intraperitoneally; groups CL and LepL) or saline (groups CSal and LepSal). The CL group showed a decrease in food intake, but no response was observed in the LepL group, suggesting leptin resistance. The Lep group demonstrated a decrease in OB-Rb expression $(-40 \%, P<0 \cdot 05)$, hyperleptinaemia $(+78 \%, P<0.05)$, hyperinsulinaemia $(+100 \%, P<0 \cdot 02)$, hypertriacylglycerolaemia $(+17 \%, P<0.05)$ and a higher protein content in the body $(+16 \%, P<0.05)$ without changes in fat mass and glycaemia. We conclude that neonatal leptin treatment programmes both hyperleptinaemia and hyperinsulinaemia in adulthood, which leads to leptin resistance by reducing the expression of the hypothalamic leptin receptor.
\end{abstract}

Leptin receptor: Rats: Lactation: Programming

Several animal experiments have shown that hormones and nutrition status, which affect development during sensitive periods early in life, permanently programme the structure and function of body tissues and systems (Walker \& Courtin, 1985, Pracyck et al. 1992; Dorner \& Plagemann, 1994; Cravo et al. 2002; Passos et al. 2002; Teixeira et al. 2003).

The mother's nutrition during lactation can programme the body weight of her offspring in adult life, and this can be mainly associated with a low-protein and higher-fat milk concentration (Trottier et al. 1998; Passos et al. 2000). The offspring of energy-restricted mothers show a lower body weight until weaning. After weaning, however, those animals were heavier than the offspring in the control group, without ingesting more food (Teixeira et al. 2002). Therefore, other factors besides food intake, especially those involved in the regulation of metabolic rate, may be responsible for those changes in body weight. We showed that malnutrition in lactating rats was associated with thyroid hyperfunction in the adult offspring (Passos et al. 2002). Changes in leptin action could also be programmed in this model (Passos et al. 2004) and theoretically affect metabolic rate.

Leptin is a protein produced by the obesity gene $(o b)$ and mainly secreted by the adipocyte, regulating food ingestion and energy balance (Schwartz et al. 1996). This hormone regulates energy disposal in the adipose tissue by specific hypothalamic signals and affects many functions, for example body weight, food intake and body temperature, as well as metabolic rate (Campfield et al. 1995; Pelleymounter et al. 1995; Schwartz et al. 1996; Friedman \& Halaas, 1998).

Leptin serum concentration changes from lactation through adulthood (Teixeira et al. 2002). It is higher in the first days of lactation, decreases thereafter, reaching its lowest level 1 week after weaning, and then progressively increases through adulthood. Malnutrition during lactation could change maternal leptin serum concentration and has been shown to change pups' leptin serum concentration (Teixeira et al. 2002). Both pups from protein-restricted mothers and pups from energyrestricted mothers presented, at weaning, higher serum leptin concentrations (Teixeira et al. 2002). As leptin is present in the milk, it is possible that this hormone is transferred to the pups through the milk (Casabiell et al. 1997; Houseknecht et al. 1997). The higher fat milk concentration in malnourished dams (Passos et al. 2000) could increase leptin production in the pups. This relationship has been demonstrated in man (Mantzoros et al. 1997) and animals (Trottier et al. 1998). We therefore hypothesized that this higher serum 
leptin at weaning could be one of the factors that programmes the endocrine disorders observed during adulthood.

Based on these findings, we developed another experimental model in which the pups were injected with murine leptin ( $8 \mu \mathrm{g} / 100 \mathrm{~g}$ body weight, subcutaneously) during the first 10 or last $10 \mathrm{~d}$ of lactation (Cravo et al. 2002). In that study, we observed that hyperleptinaemia in both the first and the last $10 \mathrm{~d}$ of lactation was associated with a higher serum leptin concentration at $150 \mathrm{~d}$ of age and, paradoxically, with a higher food intake and body weight. We thus hypothesized that these animals show resistance to the anorectic effect of leptin, as observed for those animals programmed by maternal malnutrition during lactation (Passos et al. 2004).

In the present study, we therefore aimed to evaluate whether leptin treatment in neonatal rats affected the anorexigenic effect of leptin as well as the expression of the hypothalamic long form of the leptin receptor $(\mathrm{Ob}-\mathrm{Rb})$ in the adult rat. In addition, we aimed to verify whether these changes could have consequences on intermediary metabolism.

\section{Methods}

Procedure

The use of the animals took place according to the guidelines of the Animal Care and Use Committee of the Biology Institute of the State University of Rio de Janeiro, which based its analysis on the principles described in the Revised Guide for the Care and Use of Laboratory Animals (Bayne, 1996). Wistar rats were kept in a room with controlled temperature $\left(25 \pm 1^{\circ} \mathrm{C}\right)$ and with artificial dark-light cycles (light period from 07.00 hours to 19.00 hours).

Within $24 \mathrm{~h}$ of birth, pups were divided into two groups:

1. Lep - subcutaneously injected with $50 \mu$ l recombinant mouse leptin (provided by the National Hormone and Pituitary Program, Harbor-UCLA Research and Education Institute, Los Angeles, CA, USA) at a dose of $8 \mu \mathrm{g} / 100 \mathrm{~g}$ body weight daily, based on Malendowicz et al. (1998), for the first $10 \mathrm{~d}$ of lactation;

2. The control (Con) group, which received instead the same volume of saline $(0.9 \% \mathrm{NaCl})$. The recombinant mouse leptin was dissolved in saline, and all the injections were made at 16.00 hours.

Within $24 \mathrm{~h}$ of birth, excess pups were removed so that only six male pups were kept per dam (three per experimental group), because it has been shown that this procedure maximizes lactation performance (Fishbeck \& Rasmussen, 1987).

After leptin injection $(2 \mathrm{~h})$ two pups from each litter (Lep and Con; $n$ 6) were randomly chosen, and blood samples were obtained by decapitation, trunk blood being collected to determine serum leptin. Four pups from each litter were randomly chosen and placed individually in the cage with free access to water and a normal diet until they were $150 \mathrm{~d}$ old.

\section{Food intake, body weight and body composition analysis}

Body weight and food intake were monitored every $4 \mathrm{~d}$ from birth until the 150th day of life. The amount of the diet ingested was calculated as the difference between the weight of food that remained in the food bin (Da) and the amount placed there $4 \mathrm{~d}$ before (Di). This was measured from weaning (21 d) until $150 \mathrm{~d}$ of age. These data were then used to calculate the daily food intake according to the formula: Food intake $(\mathrm{g})=(\mathrm{Di}-\mathrm{Da}) / 4$, in which 4 corresponds to the number of days.

Body composition (fat and protein mass) was determined at $150 \mathrm{~d}$ by carcass analysis as reported previously (Leshner \& Litwin, 1972). After being killed, the animals were eviscerated, and the carcasses were weighed, autoclaved for $1 \mathrm{~h}$ and homogenized in distilled water $(1: 1 \mathrm{w} / \mathrm{v})$. Samples of the homogenate were stored at $4{ }^{\circ} \mathrm{C}$ for analysis. Three grams of homogenate were used to determine fat mass gravimetrically (Stansbie, 1976). The samples were hydrolysed in a shaking water bath at $70^{\circ} \mathrm{C}$ for $2 \mathrm{~h}$ with $30 \% \mathrm{KOH}$ and ethanol. The total fat acids and free cholesterol were removed by three successive washings with petroleum ether. After drying overnight in a vacuum, all the tubes were weighed, and the results were expressed as $\mathrm{g}$ fat per $100 \mathrm{~g}$ carcass. Protein mass was determined in $1 \mathrm{~g}$ homogenate. The tubes were centrifuged at $2000 \mathrm{~g}$ for $10 \mathrm{~min}$. The total protein concentrations were determined by the method of Lowry et al. (1951). The results were expressed as g protein per $100 \mathrm{~g}$ carcass.

The retroperitoneal white adipose tissue (RPWAT) was excised and immediately weighed for evaluation of central adiposity.

\section{Leptin resistance test}

Peptide. Recombinant mouse leptin (PeproTech, Inc., Rocky Hill, NJ, USA) was dissolved in saline vehicle $(0.9 \% \mathrm{w} / \mathrm{v})$ and given as bolus injection at a dose of $0.5 \mathrm{mg} / \mathrm{kg}$ body weight intraperitoneally (Martin et al. 2000; Passos et al. 2004).

Feeding study. At $150 \mathrm{~d}$, the rats in each experimental group (Lep, Con) were randomized to one of the following groups: leptin (LepL, CL) or saline (LepSal, CSal). The animals were deprived of food for $24 \mathrm{~h}$ while maintaining free access to water before the test. After the intraperitoneal injections of leptin or saline, they were returned to their home cages and provided with a supplementary amount of a standard diet. They were housed singly, and food intake was measured by weighing the food cups 2, 4, 6 and $24 \mathrm{~h}$ after the leptin or saline injections (Martin et al. 2000; Passos et al. 2004).

\section{Serum leptin, insulin, glucose and triacylglycerol analysis}

At $150 \mathrm{~d}$ of age, the animals were killed by decapitation and trunk blood was collected and centrifuged, the serum being stored at $-20^{\circ} \mathrm{C}$ until the assay for leptin, insulin and triacylglycerol. Leptin was measured by RIA kit (Linco Research, Inc., St. Charles, MO, USA). This kit measures both rat and mouse leptin with an assay sensitivity of $0.5 \mathrm{ng} / \mathrm{ml}$ and a range of detection of $0 \cdot 5-50 \mathrm{ng} / \mathrm{ml}$. The interassay and intraassay variations were $3.1 \%$ and $4.2 \%$, respectively. Insulin was measured by RIA kit (Linco Research, Inc.), with an assay sensitivity of $0 \cdot 1 \mathrm{ng} / \mathrm{ml}$ and a range of detection of $0 \cdot 1-10 \mathrm{ng} / \mathrm{ml}$. The interassay and intra-assay variations were $2.2 \%$ and $8.9 \%$, respectively. Triacylglycerols were measured colorimetrically using a commercial kit (Bioclin, Belo Horizonte, Brazil). Glycaemia was measured by the 
glucose-oxidase method and read in a reflectance glucometer (ACCU-CHEK Advantage; Roche Diagnostics, Mannheim, Germany).

\section{Western blot of the hypothalamic leptin receptor}

The hypothalamic tissues were homogenized on ice-cold lysis buffer (50 mM-Hepes, pH 6.4, 1 mM- $\mathrm{MgCl}_{2}, 10 \mathrm{mm-EDTA \text {, }}$ Triton X-100 $1 \%, 1 \mathrm{mg} / \mathrm{ml}$ aprotinin, $1 \mathrm{mg} / \mathrm{ml}$ leupeptin, $1 \mathrm{mg} / \mathrm{ml}$ SBTI). The homogenates were stored at $-20^{\circ} \mathrm{C}$. The protein concentration was determined by the method of Bradford (1976).

The proteins $(40 \mu \mathrm{g})$ were separated by SDS-PAGE (12\%) and transferred to a nitrocellulose membrane (Hybond ECL; Amersham Pharmacia Biotech, London, UK). Membrane was blocked for 30 min with $2 \%$ bovine serum albumin in TBS-T buffer (20 mM-TRIS, pH 7.5, 0.5 M-NaCl, $0 \cdot 1 \%$ Tween 20$)$, incubated with OB-R (m-18, goat polyclonal, Sc-1834, antihuman leptin receptor; Santa Cruz Biotechnology, Santa Cruz, CA, USA) and IgG primary antibody (1:1000) in TBS-T overnight, washed three times with TBS-T and incubated with secondary antibody (peroxidase-conjugated donkey $\operatorname{IgG}, 1: 1000$ ), for $1 \mathrm{~h}$. After the membrane had been washed three times with TBS-T, antibody-binding was visualized using 3,3'-diaminobenzidine tetrahydrochloride $(5 \mathrm{mg}$ in $10 \mathrm{ml}$ Tris buffer, $0 \cdot 1 \mathrm{M}$, $\mathrm{pH}$ 7.4). The results were normalized with actin. Densitometry analyses of the immunoreactive bands were determined by Proplus image software (Infaimon, Barcelona, Spain).

\section{Statistical analysis}

The data are reported as means with standard errors. Two-way ANOVA and Newman-Keuls multiple comparison tests were used to analyse food intake in response to the acute leptin treatment. The other experimental data were analysed by Student's $t$ test with the significance level set at $P<0 \cdot 05$.

\section{Results}

\section{Body composition}

The pups' body weight during the first $10 \mathrm{~d}$, corresponding to the period of leptin treatment, is shown in Fig. 1(a); during this time, rats in the Lep group had a lower body weight (approximately $10 \%, P<0.0001$ ) from the second day of leptin injection. After weaning, the Lep group had a higher body weight (approximately $10 \%, P<0.05$ ) from day 69 onward (Fig. 1(b)). Food intake was higher in Lep group (approximately $14 \%, P<0.05$ ) on days 97 and 113 , and from day 133 onward (Fig 1(c)). Despite rats in the Lep group showing a higher body weight gain as adults, their fat mass and RPWAT were no different from those of controls (Fig. 2(a) and (d), respectively). However, they had a higher protein mass than the Con group, suggesting that this increase in body weight was due to the lean mass (Fig. 2(b)).

\section{Serum leptin}

Figure 3(a) shows the serum leptin concentration at $10 \mathrm{~d}$ of age, $2 \mathrm{~h}$ after the last leptin injection. The Lep group had higher serum leptin $(+136 \%, P<0.05)$ than the Con group, confirming the hyperleptinaemia. The serum leptin concentrations at $150 \mathrm{~d}$ of age are shown in Fig. 3(b). Again, the Lep group had higher serum leptin concentrations than the Con group $(+78 \%, P<0.05)$.

\section{Serum insulin, glucose and triacylglycerols}

The serum insulin, glucose and triacylglycerols concentrations at $150 \mathrm{~d}$ of age are given in Fig. 4. The Lep group had higher serum insulin $(+100 \%, P<0.02$; Fig. 4(a)) and higher serum triacylglycerols concentrations $(+17 \%, P<0.05)$ than the Con group (Fig. 4(c)), but no changes were observed in terms of glycaemia (Fig. 4(b)).

\section{Leptin resistance test}

Figure 5 shows the results of the leptin resistance test. The effectiveness of the test is demonstrated by the results for the Con group, in which leptin treatment significantly suppressed food intake $\left(F_{1,40}=16.52 ; P<0.002\right)$ at $2 \mathrm{~h}(-42 \%, P<0.05), 4 \mathrm{~h}$ $(-38 \%, P<0.02)$ and $6 \mathrm{~h}(-36 \%, P<0.05)$ after leptin injection, compared with the group that received saline (Fig. 5(a)). However, the LepL group did not show a similar decrease in any of the periods studied, suggesting a resistance to the anorectic effect of leptin. In addition, the LepL group rats showed an increase in food intake $\left(F_{1,40}=23 \cdot 14, P<0.001\right)$ at $2 \mathrm{~h}$ and $4 \mathrm{~h}$ (Fig. 5(b)). When the Con groups (CSal, LepSal) were compared after fasting for $24 \mathrm{~h}$, it was observed that the LepSal group consumed less food at 2, 4 and $6 \mathrm{~h}(P<0 \cdot 05)$ after saline injection (Fig. 5(c)). Even when the food intake was normalized per $100 \mathrm{~g}$ body weight, the results were similar, which reinforces the results described earlier.

\section{Western blot of the hypothalamic leptin receptor}

Western blots of total protein lysates from the hypothalamus of adult rats are shown in Fig. 6. The levels of OB-Rb were reduced by $40 \%(P<0.05)$ in Lep rats compared with the Con group.

\section{Discussion}

The major finding of the present study is that neonatal leptin treatment programmed a higher body weight, a higher body protein content, higher serum leptin level and leptin resistance, with reduced levels of the hypothalamic leptin receptor, OB$\mathrm{Rb}$. We previously showed that this kind of treatment programmed a higher body weight and food intake (Cravo et al. 2002). In agreement with other authors (Ahima et al. 1998; Mistry et al. 1999; Oates et al. 2000; Proulx et al. 2001) and with our previous findings (Cravo et al. 2002), leptin injected peripherally increased the serum leptin concentration during the neonatal period.

The higher body weight in the Lep group does not seem to be related to food intake since the gain of body weight occurs around the 70th day, whereas the increase of food intake occurs around day 133 of age. In addition, despite the higher body weight, the fat mass remained stable, suggesting that the proportion of protein in the carcass played an important role in the increase of the body weight. Although there are studies on the earlier effects of leptin treatment, there has been 

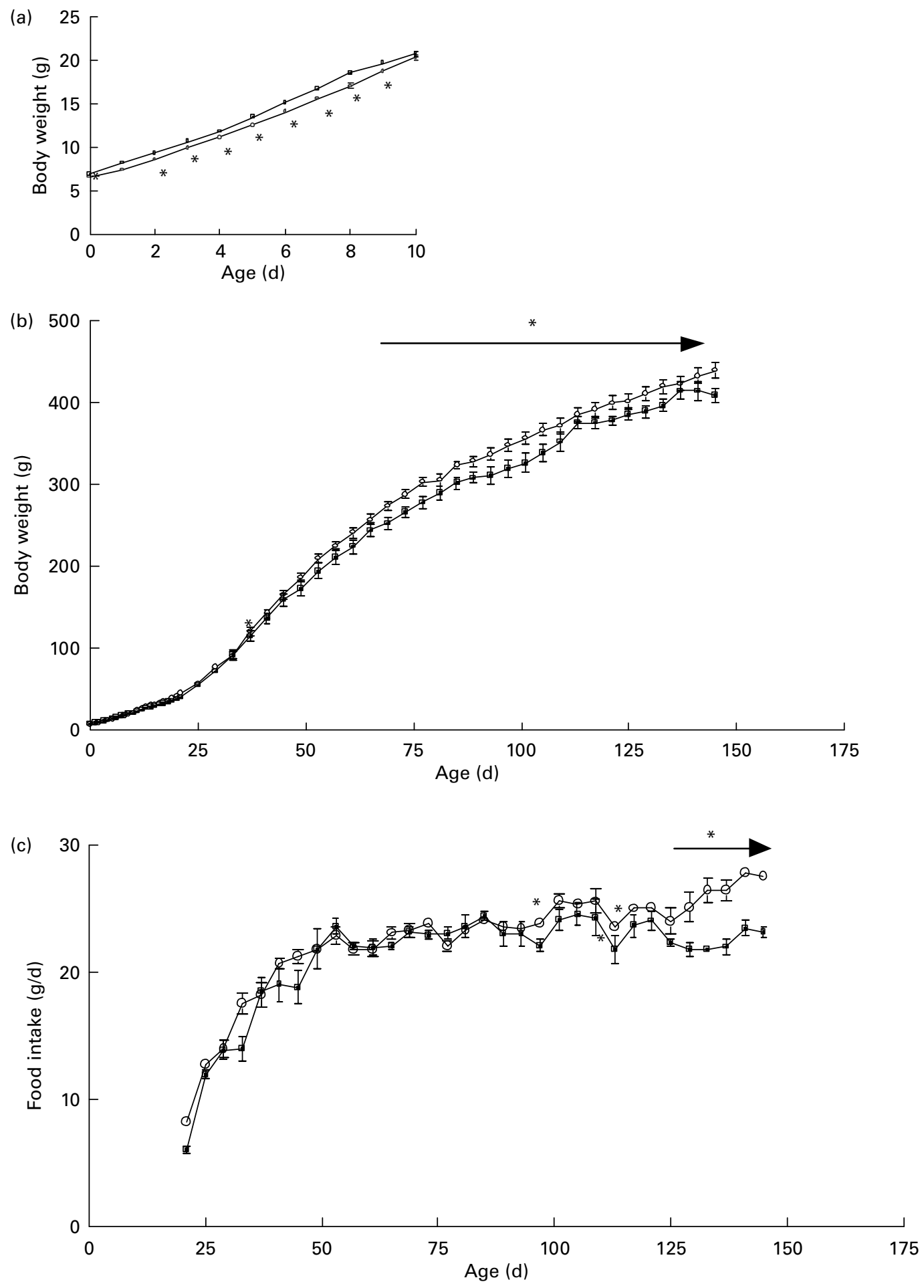

Fig. 1. Body weight from birth until $10 \mathrm{~d}$ of age (a), body weight (b) and food intake (c) from weaning to adulthood of pups that were given daily injections of leptin for the first $10 \mathrm{~d}$ of lactation $(\mathrm{O})$, and controls $(\boldsymbol{\square})$, which received the same volume of saline. Values are given as the mean with their standard errors for twelve animals per group. Mean values were significantly different between the treated and control groups: ${ }^{*} P<0.05$. For details of procedures, see $p$. 831.

no report on the long-term consequences of this treatment on body composition, mainly on the body's protein content.

Leptin and leptin receptor expression were both detected in skeletal muscle (Wang et al. 1998; Steinberg \& Dyck, 2000; Maroni et al. 2003), but there are few data on the effect of leptin on skeletal muscle. The only study on the effect of leptin on protein synthesis in skeletal muscle showed that it indirectly decreased amino acid incorporation into rat skeletal muscle (Carbo et al. 2000). If the leptin resistance observed by us were also peripheral, it could explain the higher body protein content. On the other hand, some studies have shown a direct effect of leptin on muscle, increasing glucose and 

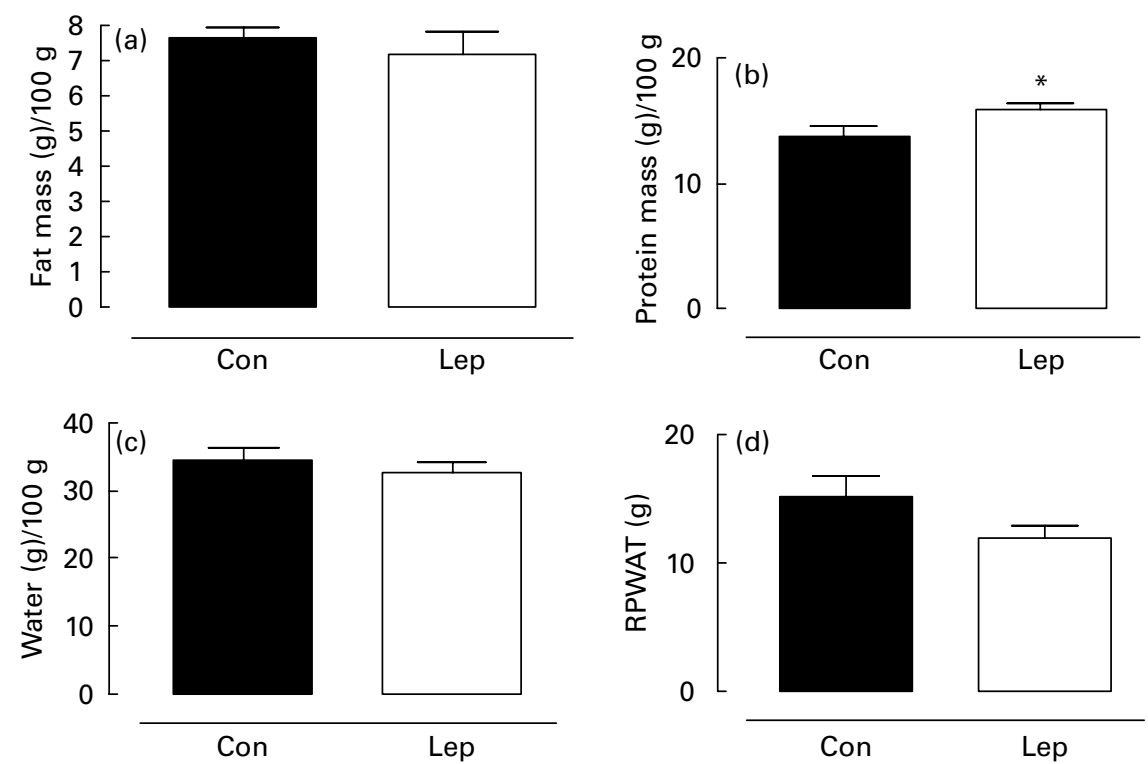

Fig. 2. Fat mass (a), protein mass (b), water content (c) and retroperitoneal white adipose tissue (RPWAT; (d)) of rats at $150 \mathrm{~d}$ of age that were given daily injections of leptin for the first $10 \mathrm{~d}$ of lactation (Lep) ( $\square$ ) and the control (Con) group ( $\square$ ), which received the same volume of saline. Values are given as the mean with their standard errors for twelve animals per group. Mean values were significantly different between the Lep and Con groups: ${ }^{*}<0.05$. For details of procedures, see p. 831 of proofs.

fatty acid metabolism (Steinberg \& Dyck, 2000; Ceddia et al. 2001). Leptin was found to stimulate growth hormone release by a stimulation of growth hormone-releasing hormone (Chan et al. 1996, Tannenbaum et al. 1998). It is known that growth
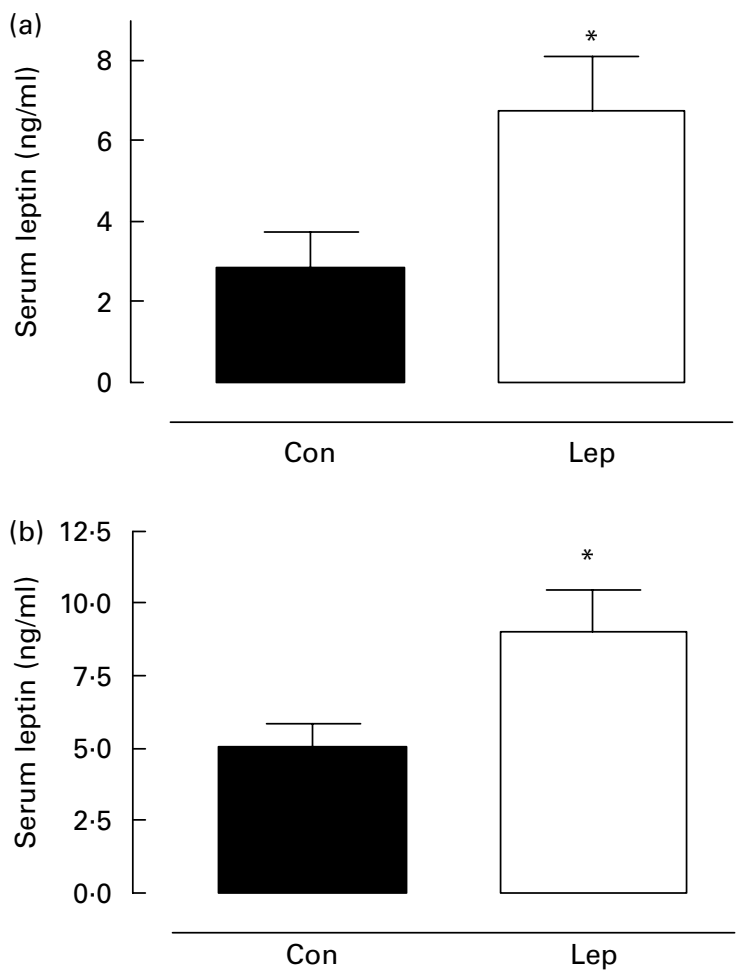

Fig. 3. Serum leptin concentration of rats at 10 (a) and $150 \mathrm{~d}$ of age (b) that were given daily injections of leptin for the first $10 \mathrm{~d}$ of lactation (Lep) ( $\square$ ) and the control (Con) group ( $\square$ ), which received the same volume of saline. Values are given as the means with their standard errors for six (a) and twelve (b) animals per group. Mean values were significantly different between the Lep and Con groups: ${ }^{*} P<0.05$. For details of procedures, see p. 831 of proofs. hormone increases amino acid uptake into muscles, increases protein synthesis and decreases protein catabolism (Casanueva \& Dieguez, 1998). It is therefore probable that, in the present study, leptin stimulated muscle protein synthesis through the action of growth hormone. To unravel this apparently conflicting interpretation, it is fundamental to study the leptin signalling pathway in muscles in this model.

In the present study, the Lep group demonstrated no change in serum glucose concentration, suggesting that these animals presented insulin resistance, since the levels of insulin were two-fold higher. Insulin is well known for its anabolic effects, and hyperinsulinaemia in the Lep group could also explain the increase in total body protein of these animals. However, as insulin has no effect on the adipose tissue of these animals, since they did not differ in total fat mass from controls, it is possible that a selective insulin resistance existed. This event of selective insulin resistance was demonstrated by Kim et al. (2000), but these authors showed that selective resistance in muscle promoted the redistribution of substrates to adipose tissue, contributing to a higher adiposity. In our model, if the selective resistance occurred in the adipose tissue, we could expect the redistribution of substrates going to the muscle.

Leptin decreases insulin sensitivity in rat adipose tissue (Muller et al. 1997). Chronic exposure to leptin has been hypothesized to promote glucose and fatty acid degradation, preventing the accumulation of triacylglycerols and consequently leading to the development of insulin resistance (Unger et al. 1999). Therefore, the insulin resistance in adipose tissue could be, in part, due to the high levels of leptin. In addition, this insulin resistance in adipose tissue would also explain the higher serum triacylglycerol levels found in the Lep group.

The usual anorexigenic response to an acute dose of peripheral leptin is not observed in those adult animals treated with leptin during early lactation; in contrast, leptin significantly 

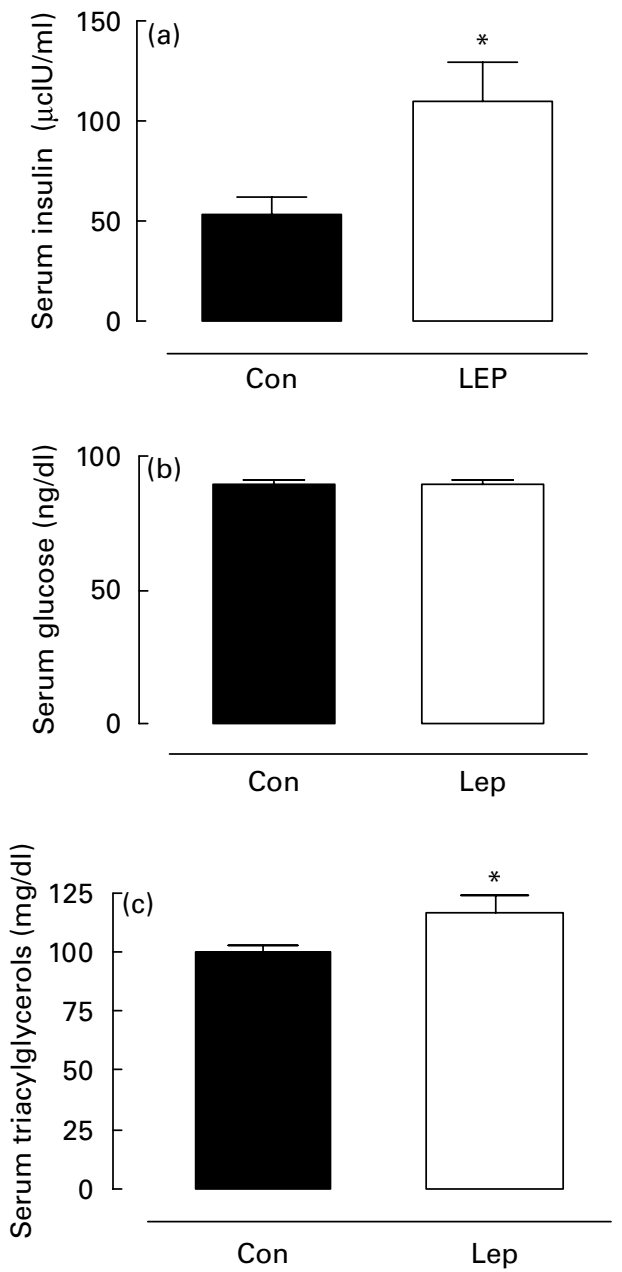

Fig. 4. Serum insulin (a), serum glucose (b) and serum triacylglycerol (c) concentrations in rats at $150 \mathrm{~d}$ of age that were given daily injections of leptin for the first $10 \mathrm{~d}$ of lactation (Lep) $(\square)$ and the control (Con) group ( $\square$ ), which received the same volume of saline. Values are given as the mean with their standard errors for twelve animals per group. Mean values were significantly different between the Lep and Con groups: ${ }^{\star} P<0.05$. For details of procedures, see p. 831 of proofs.

suppressed food intake in the Con groups, as early as $2 \mathrm{~h}$, as expected (Lin et al. 2001; Passos et al. 2004). These data suggest that the leptin administered during early lactation could programme hypothalamic leptin resistance. This resistance was also shown by other authors in adult rats submitted to chronic treatment with leptin (Martin et al. 2000) and in response to a high-fat diet (Lin \& York, 1998), both groups showing a higher serum leptin concentration, similar to the present study. The present study is thus the first to associate hyperleptinaemia during lactation with leptin resistance in adult animals.

Leptin resistance may occur for one of several reasons: leptin may fail to cross the blood-brain barrier, the hypothalamic receptors may be downregulated or there may be abnormalities in the leptin receptor signalling pathway, for example an inhibition of the JAK2-STAT3 pathway or the phosphatidylinositol-3 kinase-phosphodiesterase 3B-cAMP pathway, followed by activation of suppressor of cytokine signalling 3 (SOCS-3; Jéquier, 2002; Sahu, 2004).
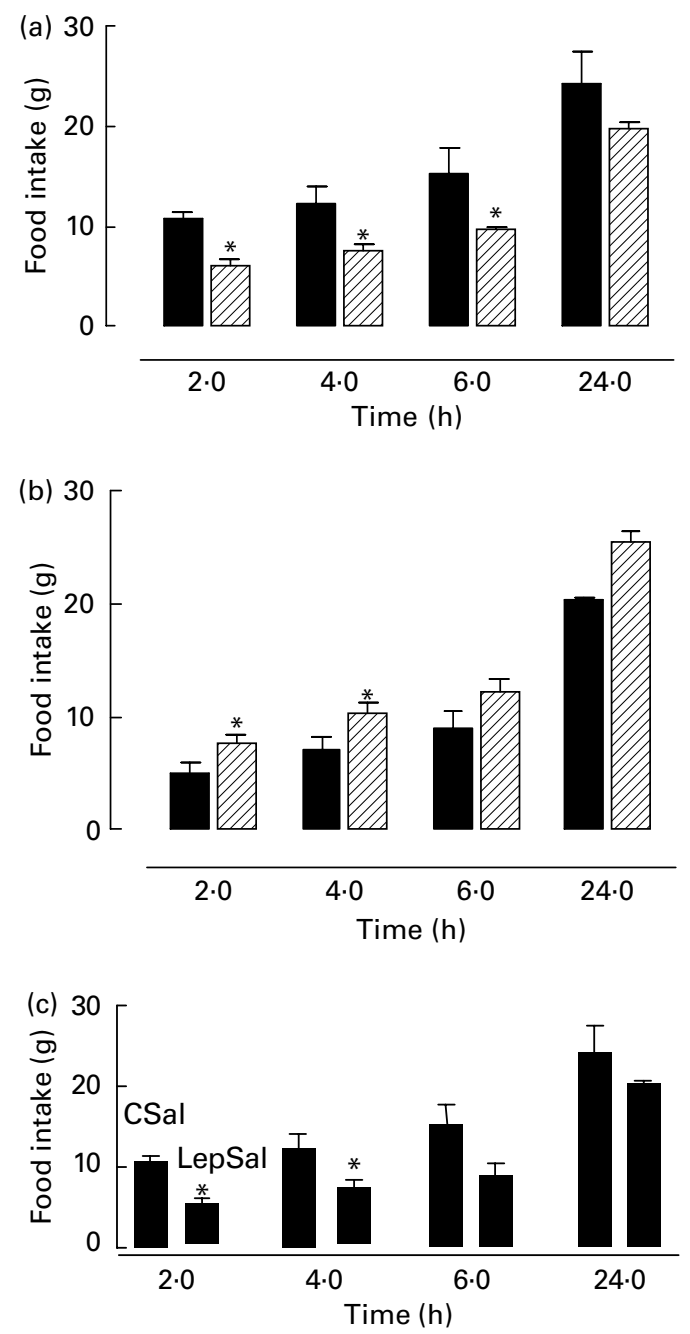

Fig. 5. The effect of the acute leptin treatment on food intake of the adult rats, which were treated with saline or leptin for the first 10 days of lactation. At 150 days, the rats of each experimental group ( $C$ and Lep) were randomized to be assigned to one of the following groups: a) $\mathbf{C S a l}$, $\mathrm{CL}$; (b) $\mathbf{\square}$ LepSal, $\square$ LepL and (c) correspond the comparison between the two controls (CSal and LepSal). Values represent the mean \pm SEM of cumulative intake; six animals per group. ${ }^{*} P<0.05$ compared with respective saline control group.

The downregulation of long-form OB-Rb attenuates the function of leptin, causing impaired signal transduction (Scarpace et al. 2001). To test the possibility of downregulation in Lep rats, we measured the OB-Rb level by western blotting and found a lower hypothalamic expression. It is likely that leptin resistance is caused by this reduction in the leptin receptor. This hypothalamic decrease in OB-Rb expression associated with higher leptin levels and consequent leptin resistance was also shown in other models of hyperleptinaemia, such as histamine-deficient transgenic rats (Hegyi et al. 2004), young rats treated with a high-fat diet (Madiehe et al. 2000; Martin et al. 2000) and diet-induced obesity rats (Levin et al. 2003).

It is well established that leptin acts at the level of the hypothalamus to reduce appetite, and there is growing evidence for an endocrine feedback system between the adipose tissue and the pancreatic $\beta$-cells via the hormones leptin and insulin, respectively. Insulin is adipogenic and increases the production of leptin by adipose tissue, whereas leptin inhibits the production of insulin in the pancreatic $\beta$-cells (Kieffer \& Habener, 2000). 

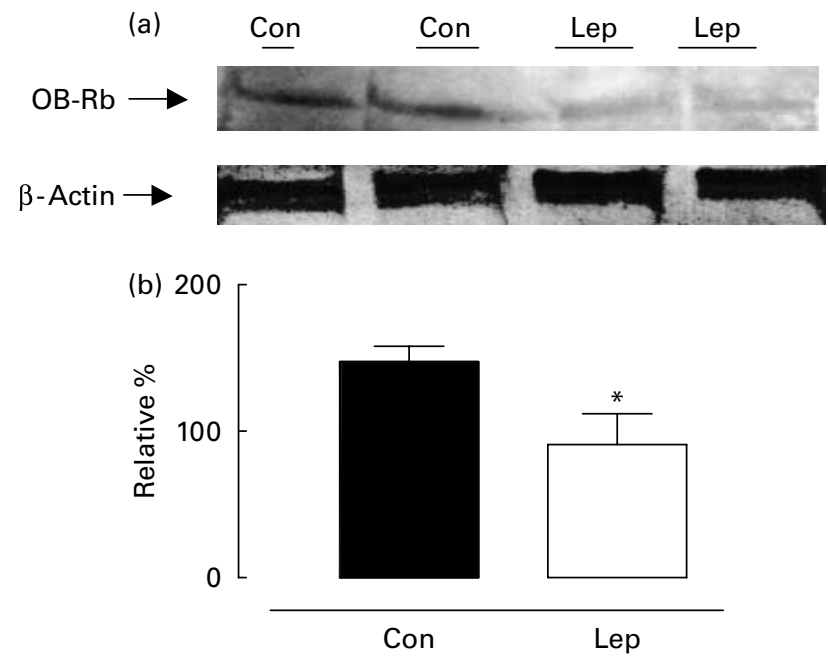

Fig. 6. (a) Western blot analysis of the hypothalamic leptin receptor (OB-Rb) in rats at $150 \mathrm{~d}$ of age that were given daily injections of leptin for the first $10 \mathrm{~d}$ of lactation (Lep), and the control group (Con), which received the same volume of saline. Also shown is the western blot analysis of $\beta$-actin. (b) Densitometric analysis of the immunoreactive bands for OB-Rb, expressed as relative (\%) to the control group (saline). Data are means and their standard errors for four animals in each group. Mean values were significantly different between the Lep and Con group: ${ }^{*} P<0.05$.

The suppressive effect of leptin on insulin production is mediated by the autonomic nervous system and by a direct action via leptin receptors on the $\beta$-cells (Kieffer \& Habener, 2000). The hyperleptinaemia in the presence of hyperinsulinism in programmed offspring suggests the development of leptin resistance at the level of the pancreatic $\beta$-cells.

Long before the discovery of the hypothalamic action of leptin, insulin was proposed as a regulator of food intake and adipose mass (Woods et al. 1979). The neurones of the arcuate nucleus express both insulin (Marks et al. 1990) and leptin (Schwartz et al. 1996) receptors. Both hormones inhibit neuropeptide Y/Agouti-related protein neurones and stimulate proopiomelanocortin neurones. The cellular and physiological responses to insulin and leptin in the hypothalamus are similar (Niswender et al. 2004). Leptin activates both the JAK/STAT pathway and the insulin-like phosphatidylinositol-3 kinase pathway in a phenomenon referred to as 'cross-talk' (Niswender et al. 2004). Both hormones augment SOCS-3 levels, which inhibit JAK/STAT phosphorylation (Elias et al. 1999). The desensitization of the OB-R system may be mediated by defective signalling induced by the increase in SOCS-3 (Ahima et al. 2000, Seufert et al. 2000).

The Lep programmed group showed both higher leptin and insulin serum concentrations. However, it seems that these animals showed hypothalamic resistance to both hormones, since they had a higher food intake than the Con group. In this paper, we describe not only resistance to leptin, but paradoxically, an increase in food intake when the rats received exogenous leptin after $24 \mathrm{~h}$ fasting. Lep animals compared with the Con group, when fasted for $24 \mathrm{~h}$, showed a lower food intake at 2, 4 and $6 \mathrm{~h}$ after saline injection. This could have happened because, during fasting, there is an acute decrease in insulinaemia and leptinaemia, reversing the leptin and insulin resistance, and allowing an anorexigenic effect of those hormones. When the rats received exogenous leptin, the higher hormone level achieved again induced leptin resistance.

Based on these findings, we hypothesize that leptin treatment during lactation increases both serum leptin and insulin in adulthood, which leads to leptin resistance by reducing the expression of the hypothalamic leptin receptor. In addition, we suggest that there is also a peripheral leptin resistance in muscle and pancreatic $\beta$-cells, as well as selective insulin resistance in the adipose tissue.

\section{Acknowledgements}

This work was supported by grants from the Conselho Nacional de Desenvolvimento Científico e Tecnológico (CNPq) and from the Fundação de Amparo a Pesquisa do Rio de Janeiro (FAPERJ).

\section{References}

Ahima RS, Prabakaran D \& Flier JS (1998) Postnatal leptin surge and regulation of circadian rhythm of leptin by feeding. J Clin Invest 101, 1020-1027.

Ahima RS, Saper CB, Flier JS \& Elmquist JK (2000) Leptin regulation of neuroendocrine systems. Front Neuroendocrinol 21, 263-307.

Bayne K (1996) Revised Guide for the Care and Use of Laboratory Animals available. Am Phys Soc Physiol 39, 208-211.

Bradford MM (1976) A rapid and sensitive method for the quantification of microgram quantities of protein utilizing the principle of protein-dye binding. Anal Biochem 72, 248-254.

Campfield LA, Smith FJ, Guisez Y, Devos R \& Burn P (1995) Recombinant mouse OB protein: evidence for a peripheral signal linking adiposity and central neural networks. Science 269, 546-549.

Carbo N, Ribas VV, Busquets S, Alvarez B, Lopez-Soriano FJ \& Argiles JM (2000) Short-term effects of leptin on skeletal muscle protein metabolism in the rat. $J$ Nutr Biochem 11, 431-435.

Casabiell X, Piñeiro V, Tomé MA, Peinó R, Diéguez C \& Casanueva FF (1997) Presence of leptin in colostrum and/or breast milk from lactating mothers: a potential role in the regulation of neonatal food intake. J Clin Endocr Metab 82, 4270-4273.

Casanueva FF \& Dieguez C (1998) Interaction between body composition, leptin and growth hormone status. Baillieres Clin Endocrinol Metab 12, 297-314.

Ceddia RB, William WN Jr \& Curi R (2001) The response of skeletal muscle to leptin. Front Biosci 6, 90-97.

Chan YY, Steiner RA \& Clifton DK (1996) Regulation of hypothalamic neuropeptide-Y neurons by growth hormone in the rat. Endocrinology 137, 1319-1325.

Cravo CO, Teixeira CV, Passos MC, Dutra SC, Moura EG \& Ramos C (2002) Leptin treatment during the neonatal period is associated with higher food intake and adult body weight in rats. Horm Metab Res 34, 400-405.

Dorner G \& Plagemann A (1994) Perinatal hyperinsulinism as possible predisposing factor for diabetes mellitus, obesity and enhanced cardiovascular risk in later life. Horm Metab Res 26, 213-221.

Elias CF, Aschkenasi C, Lee C, Kelly J, Ahima RS, Bjorbaek C, Flier JS, Saper CB \& Elmquist JK (1999) Leptin differentially regulates NPY and POMC neurons projecting to the lateral hypothalamic area. Neuron 23, 775-786.

Fishbeck KL \& Rasmussen KM (1987) Effect of repeated cycles on maternal nutritional status, lactational performance and litter growth in ad libitum-fed and chronically food-restricted rats. J Nutr 117, 1967-1975. 
Friedman JM \& Halaas JL (1998) Leptin and the regulation of body weight in mammals. Nature 395, 763-770.

Hegyi K, Fülöp KA, Kovács KJ, Falus A \& Tóth S (2004) High leptin level is accompanied with decreased long leptin receptor transcript in histamine deficient transgenic mice. Immunol Letts 92, 193-197.

Houseknecht KL, McGuire MK, Portocarrero CP, McGuire MA \& Beerman K (1997) Leptin is present in human milk and is related to maternal plasma leptin concentration and adiposity. Biochem Biophys Res Commun 240, 742-747.

Jéquier E (2002) Leptin signaling, adiposity, and energy balance. Ann N Y Acad Sci 967, 379-388.

Kieffer TJ \& Habener JF (2000) The adipoinsular axis: effects of leptin on pancreatic beta-cells. Am J Physiol 278, E1-E14.

Kim YB, Uotani S, Pierroz DD, Flier JS \& Kahn BB (2000) In vivo administration of leptin activates signal transduction directly in insulin-sensitive tissues: overlapping but distinct pathways from insulin. Endocrinolology 141, 2328-2339.

Leshner AL \& Litwin VA (1972) A simple method for carcass analysis. Physiol Behav 9, 282-289.

Levin BE, Dunn-Meynell AA, Ricci MR \& Cummings DE (2003) Abnormalities of leptin and ghrelin regulation in obesity-prone juvenile rats. Am J Physiol Endocrinol Metab 285, 949-957.

Lin L, Martin A, Schaffhauser O \& York DA (2001) Acute changes in the response to peripheral leptin with alteration in the diet composition. Am J Physiol Regul Integr Comp Physiol 280, 504-509.

Lin L \& York DA (1998) Chronic ingestion of dietary fat is a prerequisite for inhibition of feeding by enterostatin. A Am J Physiol Regul Integr Comp Physiol 275, 619-623.

Lowry OH, Rosebrough NJ, Farr AL \& Randall RJ (1951) Protein measurement with the Folin phenol reagent. J Biol Chem 193, 265-275.

Madiehe AM, Schalfhauser AO, Braymer DH, Bray GA \& York DA (2000) Differential expression of leptin receptor in high and low-fat-fed Osborne-Mendel and $\mathrm{S} 5 \mathrm{~B} / \mathrm{Pl}$ rats. Obes Res 8, 467-474.

Malendowicz LK, Macchi C, Nussdorfer GG \& Nowak KW (1998) Acute effects of recombinant murine leptin on rat pituitary-adrenocortical function. Endocr Res 24, 235-246.

Mantzoros CS, Varvarigou A, Kaklamani VG, Beratis NG \& Flier JS (1997) Effect of birth weight and maternal smoking on cord blood leptin concentrations of full-term and preterm newborns. J Clin Endocrinol Metab 82, 2856-2861.

Marks JL, Porte D Jr, Stahl WL \& Baskin DG (1990) Localization of insulin receptor mRNA in rat brain by in situ hybridization. Endocrinology 127, 3234-3236.

Maroni P, Bendinelli P \& Piccoletti R (2003) Early intracellular events induced by in vivo leptin treatment in mouse skeletal muscle. Mol Cell Endocrinol 201, 109-121.

Martin RL, Perez E, He YJ, Dawson R \& Millard WJ (2000) Leptin resistance is associated with hypothalamic leptin receptor mRNA and protein downregulation. Metabolism 49, 1479-1484.

Mistry AM, Swick A \& Romsos DR (1999) Leptin alters metabolic rates before acquisition of its anorectic effect in developing neonatal mice. Am J Physiol Journal Physiology 46, 742-747.

Muller G, Ertl J, Gerl M \& Preibisch G (1997) Leptin impairs metabolic actions of insulin in isolated rat adipocytes. J Biol Chem $\mathbf{2 7 2}$ 10585-10593.

Niswender KD, Baskin DG \& Schwartz MW (2004) Insulin and its evolving partnership with leptin in the hypothalamic control of energy homeostasis. Trends Endocrinol Metab 15, 362-369.

Oates M, Noodside B \& Walker CD (2000) Chronic leptin administration in developing rats reduces stress responsiveness partly through changes in maternal behavior. Horm Behav 37, $366-376$.
Passos MCF, Ramos CF, Dutra SCP, Mouço T \& Moura EG (2002) Long-term effects of malnutrition during lactation on the thyroid function of offspring. Horm Metab Res 34, 40-43.

Passos MCF, Ramos CF \& Moura EG (2000) Short and long term effects of malnutrition in rats during lactation on the body weight of offspring. Nutr Res 20, 1603-1612.

Passos MCF, Vicente LL, Lisboa PC \& Moura EG (2004) Absence of anorectic effect to acute peripheral leptin treatment in adult animals whose mothers were malnourished during lactation. Horm Metab Res 36, 625-629.

Pelleymounter MA, Cullen MJ, Baker MB, Hecht R, Winters D, Boone T \& Collins F (1995) Effects of the obese gene product on body weight regulation in ob/ob mice. Science 269, 540-543.

Pracyck JB, Seidler FJ, McCook EC \& Slotkin TA (1992) Pituitarythyroid axis reactivity to hyper- and hypothyroidism in the perinatal period: ontogeny of regulation and long term programming of responses. J Dev Physiol 18, 105-109.

Proulx K, Clavel S, Nault G, Richard D \& Walker CD (2001) High neonatal leptin exposure enhances brain GR expression and feedback efficacy on the adrenocortical axis of developing rats. Endocrinology 142, 4607-4616.

Sahu A (2004) Leptin signaling in the hypothalamus: emphasis on energy homeostasis and leptin resistance. Front Neuroendocrinol 24, 225-253.

Scarpace PJ, Matheny M \& Turner N (2001) Hypothalamic leptin resistance is associated with impaired leptin signal transduction in aged obese rats. Neuroscience 104, 1111-1117.

Schwartz MW, Seeley RJ, Campfield LA, Burn P \& Baskin DG (1996) Identification of targets of leptin action in rat hypothalamus. $J$ Clin Invest 98, 1101-1106.

Seufert, JR, Laubner K \& Jakob FJ (2000). Signaling and gene regulation by leptin in pancreatic beta-cells involves suppressor of cytokine signaling 3 (SOCS-3). 82nd Annual Meeting of the Endocrine Society, Toronto, Canada (abstract 1219).

Stansbie D (1976) Regulation of the human pyruvate dehydrogenase complex. Clin Sci Mol Med 51, 445-452.

Steinberg GR \& Dyck DJ (2000) Development of leptin resistance in rat soleus muscle in response to high-fat diets. Am J Physiol Endocrinol Metab 279, E1374-E1382.

Tannenbaum GS, Gurd W \& Lapointe M (1998) Leptin is a potent stimulator of spontaneous pulsatile growth hormone $(\mathrm{GH})$ secretion and the $\mathrm{GH}$ response to GH-releasing hormone. Endocrinology 139, 3871-3875.

Teixeira CV, Passos MCF, Ramos CF, Dutra SCP \& Moura EG (2002) Leptin serum concentration in rats whose mothers were submitted to malnutrition during lactation. J Nutr Biochem 13, 493-498.

Teixeira CV, Ramos CDF, Mouço T, Passos MCF \& Moura EG (2003) Leptin injection during lactation alters thyroid function in adult rats. Horm Metab Res 35, 367-371.

Trottier G, Koski KG, Brun T, Toufexis DJ, Richard D \& Walker CD (1998) Increased fat intake during lactation modifies hypothalamicpituitary-adrenal responsiveness in developing rat pups: a possible role for leptin. Endocrinology 139, 3704-3711.

Unger RH, Zhou YT \& Orci L (1999) Regulation of fatty acid homeostasis in cells: novel role of leptin. Proc Natl Acad Sci USA 96, 2327-2332.

Walker P \& Courtin F (1985) Transient neonatal hyperthyroidism results in hypothyroidism in the adult rat. Endocrinology 116, $2246-2250$.

Wang J, Liu R, Hawkins M, Barzilai N \& Rossetti L (1998) A nutrient-sensing pathway regulates leptin gene expression in muscle and fat. Nature 393, 684-688.

Woods SC, Lotter EC, McKay LD \& Porte D Jr (1979) Chronic intracerebroventricular infusion of insulin reduction reduces food intake and body weight of baboons. Nature 282, 503-505. 